Whether or not they nested is not known, but in the light of the following record, it is quite probable. These birds were a fair distance southeast of their normal summer range.

Oregon Junco (Junco oreganus). At least one pair nesited and raised young in southwest Calgary (Fish Creek); east of the recorded nesting range in the mountains.

White-throated Sparrow (Zonotrichia albicollisQ. White-throated Sparrows are regarded as occurring only as migrants in southern Alberta; but in 1968 this species was recorded from three areas in Calgary and two northwest of Calgary. In at least two areas of Calgary young were raised. Also White-throated Sparrows were seen in the second Vermilion Lakes area (three on May 15 and one on May 8-Dave Thomae, pers. comm.Q. The only other known observation of this species from the mountains is a pair in June of 1966 at Vermilion Lakes.

Smith's Longspur (Calcarius pictus). On September 14, a male in fall plumage was seen about 45 miles northwest of Calgary. This is the only record from this area for several years.

\section{WINTER PIGEON HAWK RECORDS AT BRANDON}

by Mrs. B. A. Robinson, 1441 - 8 th Street, and Miss Mamie McCowan, 1415-8th Street, Brandon, Manitoba

Because sightings of the Pigeon Hawk (Falco columbarius) in winter months are uncommon in Manitoba, the following records made in or near Brandon during the past few years may be of interest.

January 1, 1963: one observed near the southern city limits.

February 6, 1966: a female was seen flying near the Brandon Fair Grounds with a Bohemian Waxwing in its talons (reported Blue Jay, 24: 99).

January 15, 21, 28, 29 and February 4, 1967: a female was seen in the same area of the Fair Grounds. House Sparrow feathers were often seen scattered across the snow in this locality.

February 3, 1968: one was seen about eight miles southeast of the city.

In the winter of 1968-69, although we did not see a Pigeon Hawk until late in February, on several occasions during the season we noticed House Sparrow and Bohemian Waxwing feathers on the snow in the Fair Grounds. In February 1969 a gentleman living in that neighborhood mentioned having seen a small hawk. We finally saw a Pigeon Hawk about five miles northwest of the city on February 23, 1969.

\section{PIGEON HAWK INFORMATION WANTED}

As part of my continued study of the Pigeon Hawk or merlin, I have recently sent a questionnaire regarding breeding populations in Saskatchewan and Alberta to observers in representative areas.

I was unable to locate observers for the following areas of Alberta: Red Deer River-Little Sandhill Creek, Rosebud, Tofield, and Carsland. If you live in any of these areas and have records spanning a period of 10 years or more, please contact me and I will send you a questionnaire. These are very important areas and your assistance will be greatly appreciated.

If any Blue Jay readers have nesting data for this species that have not been previously recorded in the Prairie Nest Records Scheme, this too would be greatly appreciated. If any have clutches of eggs of this species collected since 1940 I will have them weighed to see if there has been a significant change in egg shell thickness since the introduction of pesticides.

The merlin has shown a marked decline in many regions and this study is one of several being made to determine the reason for the decline, and if possible, to prevent its becoming an endangered species. YOUR COOPERATION IS NECESSARY.

Glen A. Fox, 65 Grange St., Guelph, Ontario. 